QUEER PALESTINE AND

THE EMPIRE OF CRITIQUE 
This page intentionally left blank 


\section{QUEER PALESTINE AND \\ THE EMPIRE OF CRITIQUE}

Sa'ed Atshan 
Stanford University Press

Stanford, California

(C) 2020 by the Board of Trustees of the Leland Stanford Junior University.

All rights reserved.

No part of this book may be reproduced or transmitted in any form or by any means, electronic or mechanical, including photocopying and recording, or in any information storage or retrieval system without the prior written permission of Stanford University Press.

Printed in the United States of America on acid-free, archival-quality paper

Library of Congress Cataloging-in-Publication Data

Names: Atshan, Sa'ed, author.

Title: Queer Palestine and the empire of critique / Sa'ed Atshan.

Description: Stanford : Stanford University Press, 2020. | Includes bibliographical references and index.

Identifiers: LCCN 2019037604 (print) | LCCN 2019037605 (ebook) | ISBN 9781503609945 (cloth) | ISBN 9781503612396 (paperback) | ISBN 9781503612402 (epub)

Subjects: LCSH: Gay liberation movement-Palestine-History. | Sexual minoritiesPolitical activity-Palestine.| Sexual minorities-Civil rights-Palestine. | Gay rights-Palestine.

Classification: LCC HQ76.8.P19 A78 2020 (print) | LCC HQ76.8.P19 (ebook) | DDC 306.76/6095694-dc23

LC record available at https://LCCN.loc.gov/2019037604

LC ebook record available at https://LCCN.loc.gov/2019037605

Cover design: Angela Moody

Cover painting: Nabil Anani, Nostalgia, 2016, acrylic on canvas, $120 \times 105 \mathrm{~cm}$.

Courtesy of Zawyeh Gallery and the artist.

Typeset by Motto Publishing Services in 10/14 Minion Pro 